\title{
DESIGN SOLUTIONS FOR RESIDENTIAL COMPLEXES WITH A SAFE SPACES APPROACH: A CASE STUDY OF GORGAN CITY
}

\author{
Mohammad Ali Tabarsa ${ }^{1 *}$, Reza Didgah ${ }^{2}$ and Maryam Ebtehaj ${ }^{3}$ \\ 1. Assistant Professor, Department of Art and Architectural Engineering, Payame Noor University, \\ Tehran Branch, Tehran, Iran \\ 2. MA Student, Department of Art and Architectural Engineering, Astarabad Non-Profit Institute, \\ Gorgan Branch, Gorgan, Iran \\ 3. MA Student, Department of Art and Architectural Engineering, Shams Non-Profit Institute, Gonbad \\ Branch, Gonbad, Iran \\ *(Corresponding Author) - M_A_Tabarsa@yahoo.com
}

\begin{abstract}
Security in residential complexes is of great importance and the functions of the city's space should provide security for everyone. However, a sense of security is more important and research shows that in Iran, a sense of security is not at an optimum level while security in Iran is much higher than in other countries. Thus, cultural planning is required to increase a sense of security. Gorgan City has the highest level of security due to the existence of historical texture and buildings in its neighborhoods. One of these neighborhoods is Doshanbei neighborhood in Gorgan. Hence, it is expected that residential complexes constructed in Gorgan also enjoy such a quality with regard to the oldness of the city. But according to exploratory studies, new buildings, including residential complexes of Mehr Housing, have been constructed with blind imitation of Western theoretical foundations and without any modeling of historical neighborhoods and are at a low level in terms of safe spaces. This applied study is a descriptiveanalytical research design with a quantitative-qualitative nature and, while examining various theories of security and Doshanbei neighborhood, came to the conclusion that five important factors of natural monitoring, control and access, territorial division, environmental quality and social participation are the principles creating security in residential complexes of Gorgan City.
\end{abstract}

Keywords: Security, residential complexes, environmental design, Gorgan

\section{INTRODUCTION}

Throughout history, urban life most needed the establishment of security. By looking at the origin of the emergence of life collectively and sedentarily, the effect of security becomes obvious. Security has two objective and subjective dimensions. The subjective dimension is more related to social components and the objective dimension is associated with physical components. Currently, attention to the basic needs of citizens in urban environments and attention to solving urban problems to reduce abnormality and increase security in public spaces are among the issues always interested by urban managers, planners and designers (Dameri et al., 2014).

Residential complexes as the context for citizens' life and activity should be able to provide a safe, healthy and sustainable environment for everyone with respect to similarities and differences between individuals and also among age, social and gender groups and appropriately respond to the need of all social strata and meet the minimum needs. This need can be investigated particularly from sensory and cultural dimensions. Space can create a sense of disorientation or attract them so that they find this space as a suitable context for their social life. On the other hand, if people do not use a space due to lack of comfort or fear, the public sphere disappears. Prevention of crimes using environmental design can be regarded as a targeted approach to reduce crimes in the artificial environments of the city, which plays a crucial and effective role in increasing social capital, improving the quality of life and enhancing citizen satisfaction and thus promoting social welfare of society (Rezaei Moqaddam et al., 2012).

Submit Date: 11.02. 2018, Acceptance Date: 27.02.2018, DOI NO: 10.7456/1080MSE/102

Research Article - This article was checked by Turnitin

Copyright $($ The Turkish Online Journal of Design, Art and Communication 


\section{STATEMENT OF THE PROBLEM}

In the contemporary era, in the western world after World War II which was accompanied by the destruction of countless residential units, the need for housing for a large population of homeless people caused the governments to turn to the construction of residential complexes in which the issue of quantity and response to a larger number was most raised (Kane Hun, 2006). This problem is happening in our country in a different way, whose signs can be clearly seen. The increasing population growth in the years after the revolution has caused the creation of young population and the need for a lot of housing is one of the consequences of this increasing population growth. This stance has led to a kind of post-World War II experience being repeated in Iran, i.e. the construction of residential complexes lacking quality and having only quantity. One of the main problems of these residential complexes includes insecure spaces and lack of a sense of security among the inhabitants of residential complexes (Mohammadzadeh, 2011).

In this context, identifying the effective factors in improving the quality of housing is one of the issues that needs to be addressed since its impacts undeniably become manifest in the spirit of individuals and also the general spirit of society. Today, security is a qualitative indicator of life in cities and social harms are considered among the most important consequences of security. Meanwhile, residential complexes are among the spaces in the context of which social abnormalities occur. The issue of security in residential complexes is one of the human and environmental factors that promote the individuals' quality of life by making a direct impact on planning and designing these complexes. Adaptation and coordination of human and environmental factors can lead to the design of residential environments which promote the residents' social life mores and culture of residence (Crawford \& Lister, 2006).

Social security and security in general have a direct relationship with urban space and construction. An appropriate urban space to a large extent provides security and an inappropriate space compromises it and prepares the ground for a variety of social harms and problems. Inappropriate urban spaces, defenseless spaces and insecure neighborhoods are among the factors threatening urban and social security. One of the reasons for continued life in traditional textures and the residents' sense of belonging to their neighborhoods is security, and living patterns and the advancement of the technology for designing new neighborhoods have changed a lot relative to the design of traditional neighborhoods, each having strengths and weaknesses and opportunities for reducing the risk of crime and even compromising it for residents from women to men and from elders to children (Newman, 1996).

Gorgan City has the highest level of security due to the existence of historical texture and buildings in its neighborhoods. One of these neighborhoods is Doshanbei neighborhood in Gorgan. Hence, it is expected that residential complexes constructed in Gorgan also enjoy such a quality with regard to the oldness of the city. But according to exploratory studies, new buildings, including residential complexes of Mehr Housing, have been constructed with blind imitation of Western theoretical foundations and without any modeling of historical neighborhoods and are at a low level in terms of safe spaces. This study aims to identify the principles of designing safe urban neighborhoods and seeks to answer the following questions within the scope of the case under study:

- What are the principles of designing safe spaces for residential complexes in Gorgan?

- How can the security of residential complexes in Gorgan be improved using the environmental design?

\section{DEFINITIONS AND CONCEPTS}

\section{Housing}

Maskan (housing) is a place name in the same paradigm as that of Maf'al, meaning a place of calm and residence, which comes from Sakan meaning calm and refers to a place where man lives. In the dictionary of Dehkhoda, Maskan (housing) means a place of being and home, house, a place of residence and a quiet place ... (Dehkhoda, 1998: 53). At the Second Conference on Human Settlements (1996) held in Istanbul,

Submit Date: 11.02. 2018, Acceptance Date: 27.02.2018, DOI NO: 10.7456/1080MSE/102 
proper housing is defined as follows: "Suitable shelter does not only mean a roof over anyone's head. Suitable shelter means comfort, proper space, proper security and physical access, property security, structural stability and durability, lighting, ventilation, proper heating system, primary infrastructures such as proper water supply, health and education, waste disposal, good environmental quality, suitable health factors and convenient and accessible place for work and basic facilities, all of which should be provided according to the abilities of people" (Dallalpour, 2000).

\section{Security}

Security literally means freedom from worry, anxiety and fear or a sense of calm and assurance. In the dictionary of Mo'ein, security has come with the meanings of safety, being safe and having no fear (Mo'ein, 2007).

In another definition, establishment of security is subject to relative relief from threats and optimal use of opportunities. Security is a set of situations and conditions that brings about stability and calm in society and in which fear of the general public is eliminated. In this way, it can be said that security means "freedom from any threat and infringement of the legitimate and legal rights and liberties of citizens" (Eze et al., 2017).

\section{Sense of security}

A sense of security is a state in which individual and social needs and demands of people are satisfied and everyone feels valued, calm and confident. In urban spaces, a sense of urban security means that citizens can move freely, communicate with their fellow citizens and engage in social activities without being threatened or faced with physical and mental violence and harassment or sexual inequality. A sense of security refers to the safety of citizens in terms of property and life, which indicates the organization, lawfulness and stability of society. Therefore, a sense of security in a society refers to citizens' mental feeling about the existence or absence of crimes and crime-causing conditions in that society, and the higher the rate of crimes and crime-causing conditions, the lower the citizens' sense of security will be (Lotfi et al., 2014).

\section{THEORETICAL FOUNDATIONS}

\section{Social security and sense of security}

In fact, social security is an identity issue and a kind of theory raised in domestic policy of countries and even international relations. However, what is meant here is social identity. Social identity is applied to the sum of features based on which a person considers himself to be a member of a group and accordingly distinguishes others from his group. Overall, it can be stated that three concepts of social security, identity security and community security have conceptual symmetry and apply to individuals who attribute the title "we" to themselves because of sharing some features. These common features can have a natural (gender) or social origin (nation). Indeed, common features that are somehow called identity are also the subject of social security. As a result, social security can be defined as follows: "Lack of fear, danger and worry in maintaining common features of social groups such as religion, language and lifestyle" (Zangi Abadi, 2008: 7).

\section{Dimensions of social security}

Security can be examined and analyzed from different dimensions and angles. What is considered in this study is its division into objective (real security) and subjective (sense of security) dimensions (Zangi Abadi, 2008: 18).

\section{Objective dimension of social security}

This dimension of security addresses the quantity of crimes, injuries and social anomalies in society. Undoubtedly, the impact of security on delinquency is among the theoretical and empirical concerns of experts and great efforts have been made in this respect. All the studies conducted in the field of

Submit Date: 11.02. 2018, Acceptance Date: 27.02.2018, DOI NO: 10.7456/1080MSE/102 
marginalization and its potential for delinquency confirm this claim. But social security in this research encompasses a broad sense. In fact, social security means the space in which a person has a clear and promising picture of his life and his family and society in the present and future. The most important indicators of this dimension of security are: (Bastani, 1990: 9)

1- Social harm rate: It refers to the problems that have a root in the malfunctioning of various economic, social and cultural institutions of the social system and on the other hand, no penalty has been specified for them in law.

2- The rate of crime and delinquency: The quantitative rate of crime and delinquency in a society represents the amount of objective security in that society.

3- Social turmoil rate: Social turmoil or anomy is applied to the critical stage of injuries and crimes in which the rate of injuries and crimes goes beyond normal limits and reaches a critical stage.

4- The ability, skill and power of the police to deal with crimes and insecurity: If police forces can show their power of action in society to deal with crimes and abnormalities by reliance on three principles of speed, accuracy and precision, the ground for the expansion of insecurity is reduced and the crime process is placed under the control of the police and in such conditions, the space for social security development is provided.

5- Coordination of relevant institutions and organizations in the field of controlling injuries and crimes: Since injuries and consequently crimes are indeed created and spread in the context of malfunctioning of different economic, cultural, judicial, police and security organizations of a social system, the need for this coordination becomes increasingly apparent.

6- Another important indicator used for security is hope for the future. Hope for the future is the product of a sense of security about the conditions of family and society. This indicator is very important in examining the relationship between security and delinquency (Zangi Abadi, 1999: 23).

\section{Subjective dimension of social security (sense of security)}

Sense of security is a psychosocial phenomenon that has different dimensions. This feeling stems from individuals' direct and indirect experiences of the conditions of the surrounding environment and various people experience them differently. The sources that provide security for various groups of society are also different and these sources are effective at different levels (Izadifar et al., 2015). Based on the foregoing, it can be mentioned that most of the topics raised as "sense of security" by citizens are related to social security. In other words, all social security components can be measured by referring to public opinion and mentality. Further, in other dimensions of security such as land security (defense or military), some aspects can be measured by getting opinions and measuring the feelings of citizens. The existence of two different objective and subjective aspects of security has caused that a heterogeneous body of literature is formed around this concept. Some consider it as an objective concept and believe that for maintaining security, military weapons are necessary and some other look for it in the balanced economic and human development of society (Bastani, 1999: 9).

\section{Security in residential buildings}

Increased incidence and spread of crime in urban environments has increasingly worried city residents about their security of life. Increasing density can have positive and negative effects on the security of residents. Concentration and community of referrers cause potential inconveniences on one hand and raise the possibility of residents' control over abnormal social behaviors on the other (Eynifar, 2007: 108). 
Creation of security in residential buildings is done through the methods in accordance with the characteristics of this kind of buildings. Generally, protection is based on the following two basic principles:

- Establishing boundaries and fences against unauthorized entry and exercising control by guards

- Creating monitoring opportunities for residents in the building through designing defined and specified spaces or electronic methods

Nevertheless, it can be stated that the hypothesis concerning inappropriate housing and crime has been proved by researchers. In better words, there is a strong correlation between unhealthy housing and delinquency of children and youths. For example, in France, $74 \%$ of cases of delinquency are seen in places with unhealthy housing. The general quality of housing plays a crucial role in the development of anomalous or desirable social behaviors. This is because housing, beyond its definition, is merely considered as a shelter and its quality is of great importance. Parents determine their social status and family hearth by choosing their place of residence (Cooper et al., 1986). Thus, numerous experts argue that the root of deviations should be sought in inappropriate residential homes and such homes play an important role in creating deviations and delinquencies and in all class societies, most offenders belong to low and inappropriate areas. Accordingly, the situation of urban areas and neighborhoods and even the number of floors of residential buildings, the quality and appearance of apartments, the quality of buildings in terms of desirability, liveliness and verdancy and enough lighting are the factors that make a considerable effect on the type of offenses committed in urban areas and neighborhoods (Safavi Moqaddam, 2010: 52).

\section{Types of protection}

Protection of buildings is provided in different ways:

Active protection: Active protection is provided through the appropriate design of the building, including the design of the building and materials used. In this method, ways of unauthorized entry to the building over which there is no control by the residents are considered.

Defensive protection: This type of protection means the creation of a fence between the outside and inside the building. These fences include safe barriers, special access methods and locks. Defensive protection also comprises strengthening parts of the building to prevent people from entering illegally.

Alarm systems and receiving devices: This method is applied when the two above-mentioned methods are ineffective. The use of alarm systems makes it possible that the aggressor who has managed to enter the building is found and caught.

Special method: Specific methods in some cases are used as much as necessary for more protection, such as the use of closed circuit television systems and so on (Talebi, 2004: 172).

\section{The role of physical environment in visible areas}

In apartment buildings, the outside space is considered as the public space and its responsibility lies with the public. The design may be divided into many parts and various parts of the outside open space may be put under the supervision of a limited number of people. Subdivisions should be made according to a specific hierarchy so that the lands are divided between the categories of buildings and every three or four apartments have a common defined space. If subdivisions create properly defined spaces for accessible paths and secondary services and entries, they are good natural deterrents against offences. Protection is completely provided when residents feel that the monitored area is their property (Challinger, 2008).

\section{Interior spaces}

Submit Date: 11.02. 2018, Acceptance Date: 27.02.2018, DOI NO: 10.7456/1080MSE/102 
Residential buildings have a space and the lands around them are defined according to specific buildings. These defined spaces are a good guide for residents and strangers and are used as private spaces. The definition of land may be created on its own when high-rise apartments are divided in small lands. The presence of internal streets strengthens the security of the site for the following reasons:

1- $\quad$ They provide direct access to all buildings by car.

2- $\quad$ They provide the traffic of pedestrians and also vehicles into the limits of the site; hence, more security is provided with the presence of people.

3- $\quad$ They provide the possibility of patrolling of control officers and necessary facilities. Additionally, internal streets are a means of identifying the position of buildings.

The area of a design should be divided in such a way that all its spaces are related to specific buildings or building complexes because lands with signs of private ownership are more secure. The spaces around the building and the open semi-public spaces should be designed such that they are visible for residents from the inside and create a sense of being exposed in people. As a result, offences are unconsciously prevented (Talebi, 2004: 178).

\section{Creating private limits and determining the movement area}

The designer uses lines to control visual and physical movements. In this way, the designer can attract and direct the observer's attention to a specific object and place. Hedges, walls, edges, sidewalks and margins are considered among the lines and axes of the design. Gates, short stairs, plants, change in the texture of pedestrian surfaces and lighting can be named as symbolic fences. It is possible to limit the entrance space using the fences mentioned above. The success of this action depends on the following four conditions:

The aggressor's ability to infer the signs for his own purposes. The ability of inhabitants of a certain space and their agents to establish control and enhance encrypted symbols for monitoring. The defined space property to determine the intruder's intentions so that these spaces create the least ground for wrong actions.

The ability of residents and their agents to fight the perpetrator and take effective measures. Since most of these compounds affect the design purpose, a successful symbolic obstacle is the one that has all of the mentioned conditions and is a combination of all of them.

Integration of recreational and welfare facilities with the limits defined in the divisions of the levels of housing projects. If the welfare facilities used by people are placed within the defined spaces, these spaces will have better performance as defensible spaces. Experience has shown that young children ( 2 to 5 years old) play outside usually near home. If this space is strengthened by means of play and is surrounded by benches, a suitable space is provided for residents. Besides, limiting the playing space of children using symbolic barriers will have a good result (Talebi, 2004: 3).

\section{Crime prevention through environmental design}

Crime prevention through environmental design (CPTED) is an approach based on the defensible space theory raised by Oscar Newman, which sees the root of all insecurity issues in society in spatial features and physical design of the environment. But the CPTED and defensible space strategies have not been successful generally in most of the low-income urban residential neighborhoods due to unfavorable physical conditions. Physical design elements including scope and territory, natural monitoring, form of construction and also designs consistent with the general culture of society, either individually or in perfect harmony with each other, can help the creation of safe environments. This approach has six key principles as follows:

Submit Date: 11.02. 2018, Acceptance Date: 27.02.2018, DOI NO: 10.7456/1080MSE/102 
1- Territory-orientedness: Neighborhood area has public, semi-public and private spacing and each resident has a sense of belonging to it. In these conditions, people outside the neighborhood and strangers are identified and controlled.

2- Supervision and watchfulness: According to this principle, anyone who has the motive for committing a crime will refrain from doing so since he knows that the neighborhood area is under the supervision of residents. Surveillance in the physical way means avoiding the creation of out-of-sight places and blind spots in public spaces and neighborhoods.

3- Access control: Control of entrances to buildings through using protective equipment such as cameras or anti-theft doors and folding locks and also limiting the entrances to local passages and alleys can reduce the grounds for committing crimes through such physical methods.

4- $\quad$ Making it difficult to commit crimes and fulfill criminal purposes: The use of mechanical and psychological barriers in criminals in the buildings keeps them away from easy commitment of crimes in every neighborhood or building.

5- Maintenance and repairs: If the territory of the neighborhood is originally designed with appropriate equipment and services (urban furniture) and can induce a positive image of the environment and its preservation to the residents, it can strengthen a sense of belonging in residents in addition to beautifying the urban landscape and eliminate the sense of committing a crime in an environment without ownership in perpetrators.

6- $\quad$ Support for social programs: Designing and planning for the creation of recreational facilities and spaces and playgrounds and sports grounds can enhance a sense of belonging to the neighborhood in residents, increase the watchful eye on the street, increase the opportunity to monitor and control the environment by citizens, strengthen social solidarity and increase self-control of the environment (Crow, 2000).

\section{RESEARCH THEORETICAL FRAMEWORK}

As previously stated, one of the legitimate rights of citizens is to be safe while being in urban spaces. This safety must be taken into account in two aspects:

A) Physiological security: It means freedom from physical harassment

B) Psychological security: It means having a sense of space and sense of domination over space, both geographically and socially, in a society

Design for security: This means protecting the building and its inhabitants against aggressors who intend to enter the building without permission to do wrong actions. To establish security, there are some methods which are different based on the type of the building performance and its dimensions. Design to organize a complete security plan should include the sum of physical controls and other techniques and control forms.

Table 1: Theorists' views on the criteria for safe space

\begin{tabular}{|l|l|}
\hline Theorists and theories & Strategies to reduce crime and increase security \\
\hline CPTED theory & $\begin{array}{l}\text { Determining territory (territory-orientedness) } \\
\text { Supervision or watchfulness } \\
\text { Access or entrance control } \\
\text { Image and maintenance of space } \\
\text { Making the target of crime difficult }\end{array}$ \\
\hline
\end{tabular}

Submit Date: 11.02. 2018, Acceptance Date: 27.02.2018, DOI NO: 10.7456/1080MSE/102

Research Article - This article was checked by Turnitin Copyright $(9$ The Turkish Online Journal of Design, Art and Communication 


\begin{tabular}{|l|l|}
\hline & Support activities \\
\hline Jane Jacobs & $\begin{array}{l}\text { Watchful eyes on the street } \\
\text { Clear demarcation between public and private spaces } \\
\text { Continuous use of walkways and mixing the uses }\end{array}$ \\
\hline Oscar Newman & $\begin{array}{l}\text { 1) Incompatibility between form, function and meaning } \\
\text { 2) Spaces without function or with intermittent function } \\
\text { 3) Lack of visual sight }\end{array}$ \\
\hline approaches & $\begin{array}{l}\text { Capacity threshold } \\
\text { Social solidarity } \\
\text { Communication with outside the neighborhood } \\
\text { Collective culture }\end{array}$ \\
\hline Esma'eil Salehi & $\begin{array}{l}\text { Being exposed by changing the structure and form of space } \\
\text { Mostafa Behzadfar }\end{array}$ \\
\hline
\end{tabular}

Source: Author (2017)

According to theorists and the criteria raised by them to measure and evaluate security in residential spaces of Doshanbei neighborhood in Gorgan, the criteria of natural monitoring, social participation, control and access, environmental quality and territorial division have been applied.

\section{RESEARCH METHOD}

The method used in this study is descriptive-analytical and is considered among the documentary studies. The technique employed in this research to investigate the security criteria is observation. In assessing the security factors of Doshanbei neighborhood in Gorgan, the impact of skeleton on security has been the focus of attention. In the present research, a non-interventional method was used for collecting resident information. These observations were done at different hours of the week. Field studies and documentarylibrary studies are among the techniques for collecting information in this research. In documentary study method, the author contributed greatly to collecting information by referring to the municipality and the Housing Foundation and using urban outreach and master plans and the project of renovating historical textures in the analysis of Doshanbei neighborhood and also understanding the intended site. Data is 
collected through field surveys, photographs, interviews and questionnaires and data analysis is made using SPSS software and correlation method of regression. Finally, according to the results obtained from field studies and understanding of the scope, design strategies and policies are provided.

\section{Introducing the scope}

The study scope is in Gorgan located in Golestan Province. Golestan Province, with regard to its geographical location, is influenced by latitude, altitude and expansion of Alborz Mountains, altitude from the ground, distance from the sea, Turkmenistan's southern deserts, local and regional winds and dense forest cover. Gorgan is one of the northern cities with temperate climate. In this region, annual rainfall is low and because of reduced air humidity, its temperature rises and a sharp difference is created between the temperature of night and day and the temperature of the coldest and hottest months of the year. The intended site is located in the suburbs of Gorgan and the southwestern side of this city, which is along Sayyad Shirazi Boulevard.

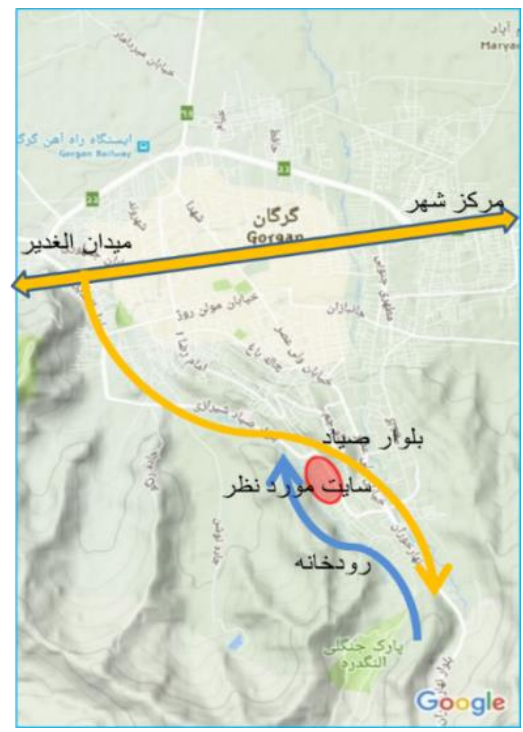

Figure 1: Site of the region

In terms of visibility and perspective, this site has a view of the high-rise residential complexes on the eastern side, which has a chaotic skyline and Sayyad hospital can also be seen from the site. The site of the complex is only fed through Sayyad Boulevard, which is a second degree access and is placed in undesigned situation in terms of access quality. The site has a rectangular geometry with the dimensions of $130 \times 202$ and an area of 26260 square meters. Moreover, the selected site has no topography or no significant gradient. In terms of access, restricting the texture through the main arteries is one of the features of the texture.

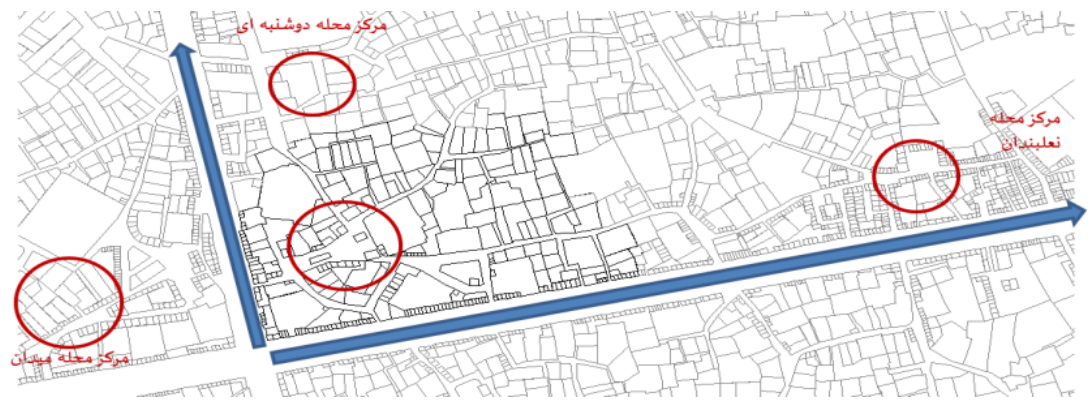

Submit Date: 11.02. 2018, Acceptance Date: 27.02.2018, DOI NO: 10.7456/1080MSE/102 
Figure 2: Accesses

Further, restricting the texture through residential masses separates its physical boundaries from other neighborhoods.

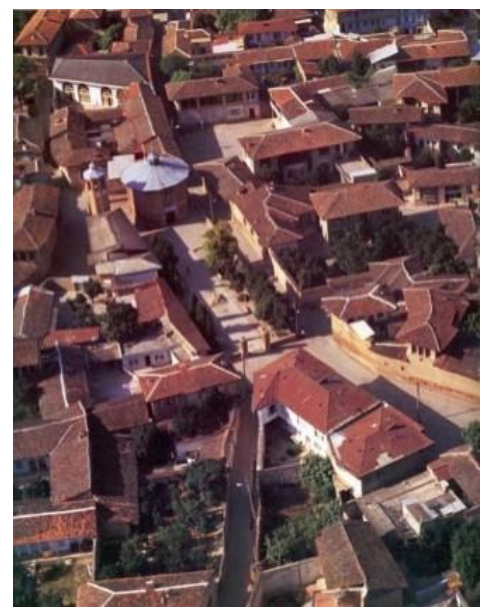

Figure 3: Residential masses of the texture

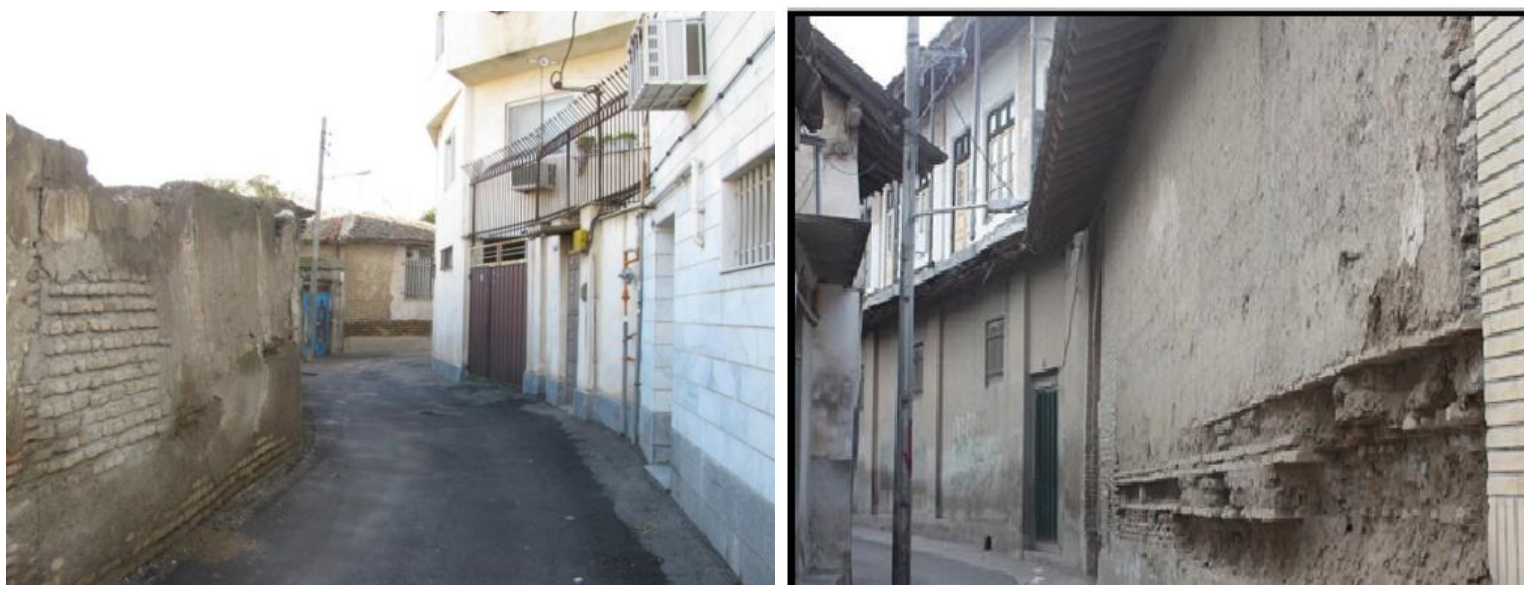

Figure 4: Introverted texture

Introverted grains of the texture which indicate secure privacy in the texture have given an introverted, strange and meandrous state to the texture.

Limited neighborhood entrances and spacing of access places (public, semi-public, semi-private and private) by the width of passageways and also deadlock alleys as spaces to catch the perpetrator and increase security are the features that make the space a safe and habitable environment based on the principles of the design approach. 

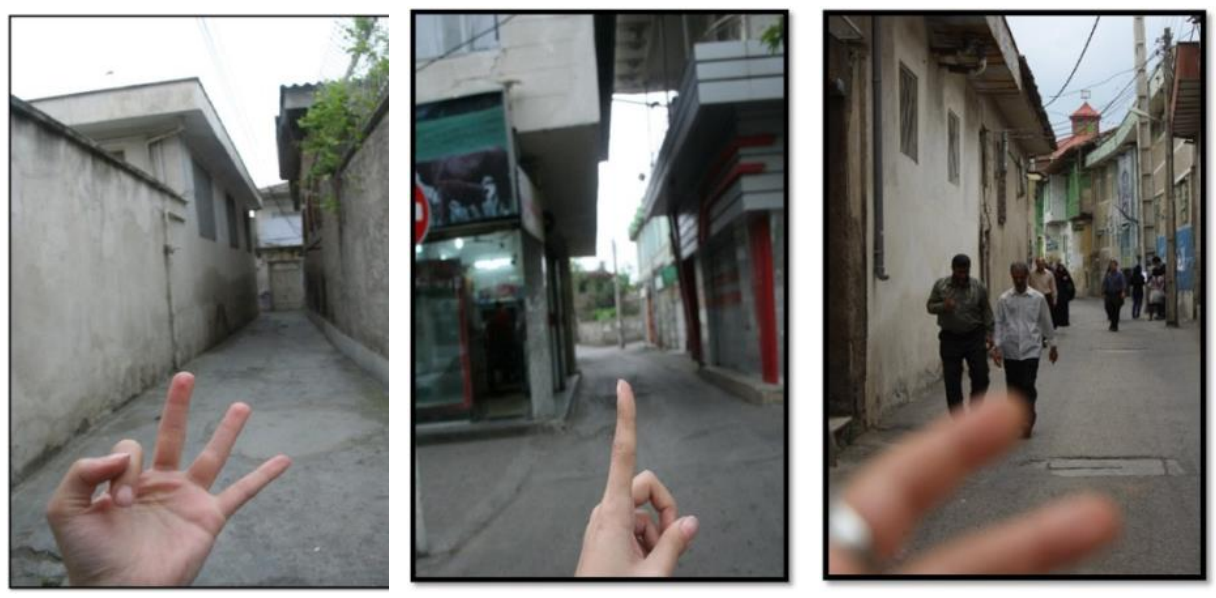

Figure 5: Spacing the access places and conditions of alleys and passages

\section{EVALUATION OF THE CASE UNDER STUDY}

The purpose of this questionnaire is to measure security criteria and factors, which has been fulfilled within a theoretical framework. By the same token, the statistical population consists of Doshanbei neighborhood in Gorgan. The sample size is calculated through Cochran formula. In this research, the sample size in this neighborhood includes 140 subjects using Cochran formula with respect to the population in outreach plans. Out of sampling methods in this survey, random or probable sampling method has been selected. In the questionnaire, the questions were designed in a closed form. For the four indicators obtained in the theoretical framework, 11 questions have been used and to assess the hypothesis, Likert spectrum has been applied, meaning that the respondents determined each of the factors on a 5-option spectrum ranging from disagree to agree.

Besides, after developing the questionnaire, it was made available to a number of professors and experts and attempt was made as much as possible that all the available experts be polled. To measure the reliability of the questionnaire, a pretest was performed in the way that initially, 20 questionnaires were distributed and collected in the target population and after entering the data, the reliability coefficient (Cronbach's alpha) was calculated using SPSS software.

Table 2: Questionnaire reliability

\begin{tabular}{|l|l|}
\hline Components & Total reliability \\
\hline Natural monitoring & 0.91 \\
\hline Social participation & 0.89 \\
\hline Environmental quality & 0.81 \\
\hline Control and access & 0.83 \\
\hline Territorial division & 0.82 \\
\hline
\end{tabular}

Cronbach's alpha coefficients for questionnaires were obtained as follows: 0.91 for natural monitoring, 0.89 for social participation, 0.81 for environmental quality, 0.83 for control and access and 0.82 for 
territorial division. This suggests the reliability of the measurement tool and internal consistency of the questionnaire.

\section{Data analysis}

In this study, the total sample size is 140 people, of whom $70.7 \%$ are male and $29.3 \%$ are female. Additionally, the age distribution of respondents in this study which was asked in the form of an open question is divided into age groups of 15 years. Moreover, the minimum age and maximum age for respondents were respectively 13 and 79 years. Also, an open question was developed for respondents' education which has been divided into 7 groups. Most of the participants had diploma education, which accounted for $49.3 \%$ of the total.

For the estimation of the impact factor and analysis of variance and calculation of the significance level of the research dependent and independent variables, linear regression was employed. The research hypotheses have been studied and tested separately in Doshanbei neighborhood and the hypothesis testing results are summarized in each neighborhood.

Table 3: Hypothesis testing

\begin{tabular}{|l|l|l|l|}
\hline Hypotheses & Standard impact & $\begin{array}{l}\text { Coefficient of } \\
\text { determination }\end{array}$ & Significance level \\
\cline { 1 - 2 } Natural monitoring affects security & 0.102 & 0.119 & 0.00 \\
\cline { 1 - 2 } Social participation affects security & 0.096 & & 0.00 \\
\cline { 1 - 2 } Environmental quality affects security & 0.022 & & 0.035 \\
\cline { 1 - 2 } Control and access affect security & 0.067 & & 0.05 \\
\cline { 1 - 2 } Territorial division affects security & 0.054 & & \\
\hline
\end{tabular}

According to the hypothesis testing table related to Doshanbei neighborhood of Gorgan, it is demonstrated that natural monitoring, social participation, environmental quality, control and access and territorial division have an impact on the security of residential spaces.

Table 4: Relationship between natural monitoring, social participation, environmental quality, control and access and territorial division with security

\begin{tabular}{|l|l|l|l|}
\hline Variable & Number & Correlation & P \\
\hline $\begin{array}{l}\text { Effect of natural } \\
\text { monitoring on security }\end{array}$ & 140 & 0.57 & 0.000 \\
\hline $\begin{array}{l}\text { Effect of social } \\
\text { participation on security }\end{array}$ & 140 & 0.49 & 0.000 \\
\hline $\begin{array}{l}\text { Effect of Environmental } \\
\text { quality on security }\end{array}$ & 140 & 0.37 & 0.000 \\
\hline Effect of control and & 140 & 0.30 & 0.000 \\
\hline
\end{tabular}

Submit Date: 11.02. 2018, Acceptance Date: 27.02.2018, DOI NO: 10.7456/1080MSE/102 


\begin{tabular}{|l|l|l|l|}
\hline access on security & & & \\
\hline $\begin{array}{l}\text { Effect of territorial } \\
\text { division on security }\end{array}$ & 140 & 0.35 & 0.000 \\
\hline
\end{tabular}

As can be observed in the above figure, out of the five indicators defining the security of residential spaces, natural monitoring with a value of 0.57 has the highest correlation coefficient with this variable. Correlation coefficient showed that there is a significant positive relationship between natural monitoring, social participation, environmental quality, control and access and territorial division with the security of Doshanbei neighborhood in Gorgan. In other words, with the improvement of the dimensions of these five indicators of residential complexes, the security of the residential complex is promoted.

In this research, by statistical analysis of the questionnaire, it was concluded that the five factors of social monitoring, environmental quality, social participation, control and access and territorial division are among the key factors in creating security in Doshanbei neighborhood. Further, by understanding and analyzing the desired site in physical, functional, environmental, cultural and social terms, possibilities, opportunities and problems of the site were identified in order to provide design solutions for secure residential complexes in the studied sample accordingly.

\section{DEVELOPMENT OF SECURE DESIGN PERSPECTIVE IN THE AREA}

The importance of perspective and perspective creating in determining the economic, social and physical destiny of cities and urban spaces and neighborhoods is such that it can be considered as the heart of the planning process and strategic urban design (Golkar, 2005: 25). In this section, a perspective was designed based on the research objectives, the initial perspective and also the results of the understanding and analysis.

Gorgan City has the highest level of security due to the existence of historical texture and buildings in its neighborhoods. It is expected that residential complexes constructed in Gorgan also enjoy such a quality with regard to the oldness of the city. But based on the studies conducted, new buildings have been constructed without any modeling of historical neighborhoods. Accordingly, perspective of the area is as follows:

The neighborhoods of Gorgan are among the places where users feel safe. The existence of specific culture and climate characteristics of this region contributes greatly to the creation of secure spaces. Among the features of historical neighborhoods of Gorgan, including Doshanbei neighborhood, are attention to defensible spaces, creation of residents' community spaces, control and monitoring of community spaces by the residents and also attention to environmental design. By using these factors, new secure residential complexes can be created.

\section{Strategies, policies and solutions for designing secure residential complexes}

In this section, considering the results of understanding and analysis and also design goals, strategies, policies and solutions are presented.

\begin{tabular}{|l|l|l|}
\hline Solution & Policy & Strategy \\
\hline $\begin{array}{l}\text { Creating a sense of ownership through arranging public, } \\
\text { semi-public, semi-private and private spaces } \\
\text { Using a terrace to create a space between public and }\end{array}$ & $\begin{array}{l}\text { Increased sense of } \\
\text { ownership }\end{array}$ & Territorial division \\
\hline
\end{tabular}

Submit Date: 11.02. 2018, Acceptance Date: 27.02.2018, DOI NO: 10.7456/1080MSE/102 


\begin{tabular}{|c|c|c|}
\hline $\begin{array}{l}\text { private areas } \\
\text { Creating specific boundaries for private areas through } \\
\text { green space, stone pavement and fencing }\end{array}$ & & \\
\hline $\begin{array}{l}\text { Mixing pedestrians and drivers } \\
\text { Locating the pedestrian in places with social monitoring } \\
\text { Using sidewalks to define the boundary of pedestrians } \\
\text { Creating hierarchy of access } \\
\text { Appropriate human dimensions for pedestrians and } \\
\text { drivers } \\
\text { Using landscape design to guide people on safe routes } \\
\text { Paying attention to locating tree planting so that there is } \\
\text { no chance of climbing trees and entering buildings and } \\
\text { homes } \\
\text { Designing a riding path visible from windows or front or } \\
\text { back doors } \\
\text { No use of dark materials for balcony shelter and patio } \\
\text { fencing } \\
\text { Driver's access to all buildings } \\
\text { Reducing the number of units with a common entrance } \\
\text { (more than four apartments should not use a common } \\
\text { entrance) }\end{array}$ & $\begin{array}{l}\text { Increasing visible } \\
\text { spaces } \\
\text { Creating defensible } \\
\text { spaces }\end{array}$ & $\begin{array}{l}\text { Improving control } \\
\text { over and access to } \\
\text { the space }\end{array}$ \\
\hline $\begin{array}{l}\text { Proper lighting for parking lots, sidewalks and } \\
\text { community spaces } \\
\text { Landscape design of the complex to enhance the sight and } \\
\text { public monitoring } \\
\text { The placement of furniture along the paths and the } \\
\text { presence of people in the space } \\
\text { Using proper infrastructure } \\
\text { Optimal and sufficient lighting at the entrances and exits }\end{array}$ & $\begin{array}{l}\text { Increasing the quality } \\
\text { of furniture } \\
\text { Increasing the quality } \\
\text { level of lighting }\end{array}$ & $\begin{array}{l}\text { Promoting } \\
\text { environmental } \\
\text { quality }\end{array}$ \\
\hline
\end{tabular}




\begin{tabular}{|c|c|c|}
\hline Mixing the uses & & \\
\hline $\begin{array}{l}\text { Trying to improve the quality of green space } \\
\text { Creating high-quality passages with their marginal green } \\
\text { space }\end{array}$ & $\begin{array}{l}\text { Promoting the } \\
\text { environmental quality } \\
\text { and green space }\end{array}$ & \\
\hline $\begin{array}{l}\text { Designing walking paths so that they can be monitored } \\
\text { from nearby homes } \\
\text { Designing a number of parking lots in the open area in } \\
\text { front of houses to increase the monitoring of the space } \\
\text { and prevention of theft }\end{array}$ & $\begin{array}{l}\text { Increasing the } \\
\text { watchful eyes on the } \\
\text { space }\end{array}$ & $\begin{array}{l}\text { Improving the level } \\
\text { of natural } \\
\text { monitoring }\end{array}$ \\
\hline $\begin{array}{l}\text { Locating green and recreational spaces where the door } \\
\text { and window of many units can be seen }\end{array}$ & & \\
\hline $\begin{array}{l}\text { Enabling human presence with service facilities to } \\
\text { increase public monitoring }\end{array}$ & & \\
\hline $\begin{array}{l}\text { Creating furniture such as telephone kiosks and } \\
\text { newsstands in crime-causing areas }\end{array}$ & & \\
\hline $\begin{array}{l}\text { Locating children's playground where they can be seen } \\
\text { from the unit window }\end{array}$ & & \\
\hline Lack of distance between houses and passages & & \\
\hline $\begin{array}{l}\text { Inserting a window to the public spaces to enhance the } \\
\text { watchful eye }\end{array}$ & & \\
\hline $\begin{array}{l}\text { Locating the entrance door of the house in a place visible } \\
\text { from the street }\end{array}$ & & \\
\hline $\begin{array}{l}\text { Putting the stair and elevator box in a place visible from } \\
\text { the residential unit }\end{array}$ & & \\
\hline $\begin{array}{l}\text { Considering enough lighting for elevators, stairs and } \\
\text { yards }\end{array}$ & & \\
\hline $\begin{array}{l}\text { Planting small trees around the sidewalk with a height of } \\
\text { less than } 1 \text { meter to maintain natural monitoring }\end{array}$ & & \\
\hline Avoiding planting trees in front of doors and windows & & \\
\hline $\begin{array}{l}\text { Not building the parking lots in the form of pilot, which } \\
\text { decreases natural monitoring }\end{array}$ & & \\
\hline Eliminating long corridors in blocks & & \\
\hline $\begin{array}{l}\text { Creating gathering spaces in areas with low visibility and } \\
\text { supervision }\end{array}$ & & \\
\hline
\end{tabular}




\begin{tabular}{|c|c|c|}
\hline $\begin{array}{l}\text { Establishing supervisory groups for residential complexes } \\
\text { The proximity of the residential use to other facilities } \\
\text { needed by people } \\
\text { Persuading residents to participate } \\
\text { Enabling safe behaviors in insecure spaces } \\
\text { Encouraging neighborhood residents to make optimal use }\end{array}$ & $\begin{array}{l}\text { Creating } \\
\text { settings } \\
\text { Increasing } \\
\text { participation } \\
\text { improve the } \\
\text { the }\end{array}$ & $\begin{array}{l}\text { Promoting the level } \\
\text { of social solidarity }\end{array}$ \\
\hline
\end{tabular}

\section{CONCLUSION}

Today, security is one of the main characteristics of the quality of life in cities, which has assumed an added importance with the expansion of urbanization and increased population density so that its reduction causes severe disruption in society and will lead to people's dissatisfaction. In fact, citizens' sense of security has an enormous impact on other issues that have a lot of feedback in the stability of the urban structure in social, economic and political terms. Among the factors defining security in cities is the rate of the social damages in them which is explained by many indicators. Security has objective and subjective dimensions. Objective dimensions can be described based on crime statistics. But the subjective dimension which is referred to as the sense of security is highly affected by psychological factors. The scope of the need for security is broader than it is supposed to be and in its improvement, the possibility of social growth and prosperity will be severely limited. Findings of this study indicate that by controlling the visual and physical symbolic access and permeability, the possibility of crimes can be controlled equally. This study, which examines security in residential complexes and aims to explain the principles of designing safe spaces for residential complexes in Gorgan and discuss the effect of the environmental design approach on the improved security of Gorgan residential complexes, has stated principles and criteria for designing safe spaces after studying the views of thinkers about the security of residential complexes and reviewing studies on the crime prevention theory through environmental design. Besides, given that historical neighborhoods of Gorgan are places with the highest security level, Doshanbei neighborhood of Gorgan has been investigated and analyzed in this study and the criteria and principles creating the security of this neighborhood were achieved and conclusion was obtained by comparing these principles with the opinions of theorists. Accordingly, by assessing these criteria through field method and questionnaire, it was determined that the five important factors of natural monitoring, control and access, territorial division, environmental quality and social participation cause to promote the level of security in Doshanbei neighborhood of Gorgan.

Moreover, in connection with the impact of environmental design approach on the promotion of security in residential complexes of Gorgan, by understanding the area and analyzing environmental and spatial conditions of the area, a series of information was obtained from the site, including facilities, issues and problems and opportunities, and accordingly, the perspective was explained and solutions and policies in relation to the five criteria for improving security were stated. 


\section{REFERENCES}

Bastani, S. (1990). Neighborly relations between apartment dwellers in Tehran. Faculty of Social Sciences, University of Tehran.

Kane Hun, T. (2008). Crime prevention through environmental design. Translated by A. Soltani (2006). Journal of police disciplinary prevention, No. 1, p. 148.

Dallalpour Mohammadi, M. R. (2000). Some planning and design considerations in the physical texture of residential complexes. Faculty of Literature and Human Sciences of Tabriz, No. 160 \& 161.

Dehkhoda, A. A. (1998). Dictionary. Tehran University Press.

Rafi'eian, M., Asgarzadeh, Z. \& Asgarzadeh, M. (2010). Evaluating the quality of residential complexes with an emphasis on satisfaction approach in Navvab neighborhood. Scientific-Research Journal of Modarres, p. 212.

Zangi Abadi, A. (2008). Analyzing and organizing the spatial structure of urban development indicators in cities with over 100,000 Iranians. PhD dissertation, supervisors: Houshang Talebi, Mahmoud Hedayat, University of Isfahan, Faculty of Literature and Humanities, Department of Geography.

Salehi, E. (2008). Environmental features of secure urban spaces. Publications of the center for research, study and architecture, First Edition, Tehran.

Safavi Moqaddam, D. (2012). Studying the satisfaction with habitation in densely populated residential complexes and reaching a desirable complex from the viewpoint of urban design. Master's thesis, Faculty of Arts and Architecture, Yazd University.

Talebi, Zh. (1997). Architectural design guide for tall residential buildings. Tehran, Building and Housing Research Center.

Eynifar, A. R. (2007). Effective human-environmental factors in designing residential complexes. Journal of Fine Arts, No. 8, p. 7.

Lotfi, S., Bardi, R., Moradnezhad, A. \& Sasanipour, M. (2014). Investigating the sense of security in public spaces: A case study of metropolis of Shiraz. Urban Research and Planning, 5 (19).

Mo'ein, M. (2005). One-volume Persian dictionary. Sahel Publications, Tehran.

Submit Date: 11.02. 2018, Acceptance Date: 27.02.2018, DOI NO: 10.7456/1080MSE/102

Research Article - This article was checked by Turnitin

Copyright $(9)$ The Turkish Online Journal of Design, Art and Communication 